\title{
Evaluation of Heavy Metals Around the Mining of Decorative Stone Ore in Susong County Liaohe River
}

\author{
SiHeng Lu, Chang Pan, YuJuan Jin, Xiang Wang, Xinlai Wei, ZhiMin Yu \\ Department of Biology and Environment Engineering, Hefei University, Hefei 230601, P. R. China. \\ Address: No. 99, Jinxiu Road, Hefei 230601, P. R. China. *Corresponding author. e-mail: \\ 1035319332@qq.com
}

\begin{abstract}
In order to study the pollution of heavy metals around Liaohe Fender stone mine in Susong County, the soils at six points and the sediment at four points were selected. The effects of heavy metals $\mathrm{Cu}, \mathrm{Zn}, \mathrm{Pb}, \mathrm{Cd}, \mathrm{Cr}, \mathrm{Ni}, \mathrm{Hg}$ and $\mathrm{As}$ were measured, the single factor index and the Nemero index method were used to evaluate the heavy metal elements in soil and sediment. The results showed that the values of heavy metal elements in the soil and sediment were less than 1 and the $P_{\text {integrated }}$ values were less than 0.85 , the mine area was not polluted by heavy metals and belonged to the clean area within the grade $I$.
\end{abstract}

Keywords:- ore rock, heavy metal; soil sediment, the single factor index, the nemero index.

\section{RESEARCH AREA}

In this paper, the mining area is the open pit mining and main mining marble, the amount of ore 110.7729 million $\mathrm{m} 3$, the range of 1.4064 square kilometers. The mining area is located in the north of Susong County, and the geographical coordinates of the center of the mining area are E $115^{\circ} 55^{\prime} 25^{\prime \prime}$ and $\mathrm{N} 30^{\circ} 21^{\prime} 37^{\prime \prime}$. The mining area is $71 \mathrm{~km}$ from the Changjiang Fuxing Town Pier, by the revival of the town pier along the Yangtze River golden waterway east to Shanghai.

\section{THE PURPOSE AND SIGNIFICANCE OFTHE STUDY}

Long-term mining of the mine not only caused soil erosion, but also led to the long-term enrichment of heavy metals during the mining process, and caused a serious threat to the surrounding soil environment.

Heavy metal generally refer to metals with a density greater than or equal to 5.0 [1], which is nondegradable persistent toxic pollutants, that dissolve, adsorb, precipitate, complex and so on in a series of migration and enrichment process in the soil [2], not only caused serious harm to the soil environment and water environment, But also through the food chain into the human body and accumulated, leading to health problems. In this paper, multi-method has been used to evaluate the heavy metal elements in the mining area, it is of great significance to provide the basis for the content of heavy metals in the mining area and to better manage the mining environment.

\section{EXPERIMENT AND DATA PROCESSING}

\section{A. Sample collection}

In the sampling area using a checkerboard sampling points, collecting the thickness of the soil in the $0-20 \mathrm{~cm}$ deep 6 points of the soil, where each point of soil samples were equely mixed with quartiles [3], the collected samples into the polyethylene plastic bag, and take back to the laboratory. The collection of its sediment along the river to the direction, a sample of 4 points was collected from the sediment layer using a sediment sampler, each sample was taken at a rate of $10 \mathrm{~cm}$ for one time [4], then mixed into a sealed bag and numbered back to the laboratory. The sampling points for soil and sediment are shown in Table 2.1 and Table 2.2 below: 
Table 2.1

Soil Point Arrangement

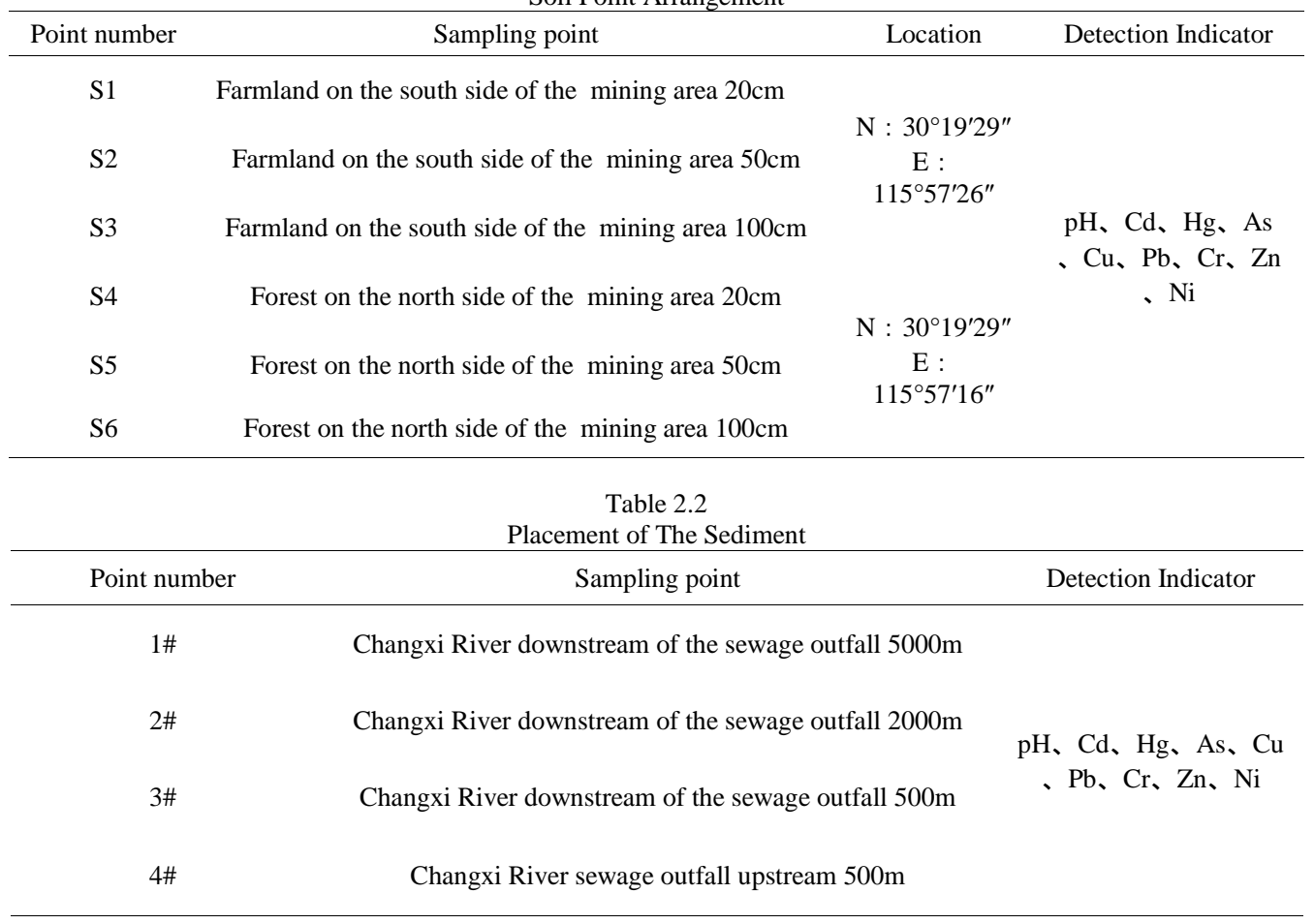

\section{B. Pretreatment of the sample}

Take $500 \mathrm{~g}$ of soil samples and sediment on the tray in the natural air-dried, polished in the glass, filter with 100 mesh nylon screen [5].

(1) Method for digestion of $\mathrm{Cu}-\mathrm{Zn}-\mathrm{Cd}-\mathrm{Cr} \mathrm{Ni}$ heavy metal hydrochloric acid - nitric acid hydrofluoric acid - perchloric acid [6].

Weigh the soil and sediment $(0.2 \sim 0.5 \mathrm{~g})$ into the digestion cup, wet with water and add $10 \mathrm{~mL}$ of hydrochloric acid to heat up to $3 \mathrm{~mL}$ on a hot plate at $80^{\circ} \mathrm{C}$, the addition of nitric acid and hydrofluoric acid $5 \mathrm{~mL}$ and $3 \mathrm{~mL}$ of high chloric acid ,then heated until the contents of the digestion cup were viscous, and the digestion cup was washed with deionized water and transfer the contents to a $50 \mathrm{~mL}$ volumetric flask.

(2) Determination of As Sulfuric Acid - Nitric Acid - Perchloric Acid [7].

Weigh $0.20 \sim 0.5 \mathrm{~g}$ sieve and sample into the $150 \mathrm{~mL}$ Erlenmeyer flask, add $7 \mathrm{~mL}$ sulfuric acid,
$10 \mathrm{~mL}$ nitric acid and $2 \mathrm{~mL}$ perchloric acid, heating on the hot plate until the liquid was white residue, adding distilled water to $50 \mathrm{~mL}$.

(3) Digestion of Hg sulfuric acid - nitric acid potassium permanganate [8].

Weigh $0.2 \sim 0.5 \mathrm{~g}$ sieve soil samples and sediment into $150 \mathrm{~mL}$ Erlenmeyer flask, add sulfuric acid, nitric acid mixture $5 \sim 1 \mathrm{~mL}$ and $10 \mathrm{~mL}$ potassium permanganate, in the hot plate for $30 \sim 60 \mathrm{~min}$. Remove the cooling, add hydroxylamine hydrochloride solution until brown, add distilled water to $100 \mathrm{~mL}$.

\section{Standard curve preparation}

According to the approximate range of the detection limit of each heavy metal $\mathrm{Cu} 1 \mathrm{mg} / \mathrm{Kg}$, $\mathrm{Zn} 0.5 \mathrm{mg} / \mathrm{Kg}, \mathrm{Pb}$ and $\mathrm{Cd} 0.2 \mathrm{mg} / \mathrm{Kg}, \mathrm{Cr}$ and Ni0.5mg / Kg [9], preparation of the standard curve, the final transfer to $50 \mathrm{~mL}$ capacity bottle, the marking gradient is shown in Table 2.3:

Table 2.3

Concentration Gradient of Each Element

\begin{tabular}{|c|c|c|c|c|c|c|}
\hline $\begin{array}{l}\text { Mixed standard } \\
\text { volume } / \mathrm{mL}\end{array}$ & 0.00 & 0.50 & 1.00 & 2.00 & 3.00 & 5.00 \\
\hline $\mathrm{Cu}(\mathrm{mg} / \mathrm{L})$ & 0.00 & 0.20 & 0.40 & 0.80 & 1.20 & 2.00 \\
\hline $\mathrm{Zn}(\mathrm{mg} / \mathrm{L})$ & 0.00 & 0.10 & 0.20 & 0.40 & 0.60 & 1.00 \\
\hline $\mathrm{Pb}(\mathrm{mg} / \mathrm{L})$ & 0.00 & 0.50 & 1.00 & 2.00 & 3.00 & 5.00 \\
\hline $\mathrm{Cd}(\mathrm{mg} / \mathrm{L})$ & 0.00 & 0.025 & 0.005 & 0.10 & 0.15 & 0.25 \\
\hline $\mathrm{Cr}(\mathrm{mg} / \mathrm{L})$ & 0.00 & 0.50 & 1.00 & 2.00 & 3.00 & 4.00 \\
\hline $\mathrm{Ni}(\mathrm{mg} / \mathrm{L})$ & 0.00 & 0.20 & 0.50 & 1.00 & 2.00 & 3.00 \\
\hline $\mathrm{Hg}(\mathrm{mg} / \mathrm{L})$ & 0.00 & 0.50 & 1.00 & 2.00 & 3.00 & 4.00 \\
\hline As (mg/L) & 0.00 & 0.50 & 1.00 & 1.50 & 2.00 & 3.00 \\
\hline
\end{tabular}


Environment. Technology. Resources, Rezekne, Latvia Proceedings of the $11^{\text {th }}$ International Scientific and Practical Conference. Volume III, 192-199

D.Sample test results

(1) Instrument type and related parameters

The $\mathrm{Cu}, \mathrm{Zn}, \mathrm{Cd}, \mathrm{Cr}$ and $\mathrm{Ni}$ heavy metals were characterized by flame atomic absorption spectrophotometry(Model AA900), for $\mathrm{Hg}$ cold atomic using absorption spectrometer (F732-VJ), As using UV-Vis spectrophotometer (Uvmini1240), The parameters of the relevant elements of flame atomic absorptionare shown in Table 2.4 [10], The determination method and the minimum detection limit for each heavy metal are shown in Table 2.5:

Table 2.4

Parameters of Flame Atomic Absorption Related Elements

\begin{tabular}{|c|c|c|c|c|}
\hline $\begin{array}{c}\text { copper } \\
\text { parameter }\end{array}$ & Wavelength $(\mathrm{nm})$ & Slit width(nm) & Lamp current(mA) & Acetylene: air \\
\hline $\mathrm{Cu}$ & 324.8 & 0.8 & 2.0 & $1: 5-1: 6$ \\
\hline $\mathrm{Zn}$ & 213.9 & 0.2 & 2.0 & $1: 4$ \\
\hline $\mathrm{Pb}$ & 283.3 & 0.8 & 2.0 & $1: 4$ \\
\hline $\mathrm{Cd}$ & 228.8 & 0.8 & 2.0 & $1: 5-1: 6$ \\
\hline $\mathrm{Cr}$ & 357.9 & 0.2 & 4.0 & $1: 2-1: 3$ \\
\hline $\mathrm{Ni}$ & 232.0 & 0.2 & 3.0 & $1: 4$ \\
\hline
\end{tabular}

Table 2.5

Determination of Heavy Metals and Minimum Detection Limit

\begin{tabular}{|c|c|c|c|}
\hline $\begin{array}{l}\text { Detection } \\
\text { Indicator }\end{array}$ & Detection method & testing base & $\begin{array}{l}\text { Detection limit or } \\
\text { minimum detection } \\
\text { concentration }\end{array}$ \\
\hline $\mathrm{pH}$ & Potential method & NY/T 1377-2007 & -- \\
\hline $\mathrm{Cd}$ & $\begin{array}{l}\text { KI-MIBK Extraction Flame Atomic Absorption } \\
\text { Spectrophotometry }\end{array}$ & GB/T 17140-1997 & 0.05 \\
\hline $\mathrm{Hg}$ & Cold atomic absorption spectrophotometry & GB/T 17136-1997 & 0.005 \\
\hline As & $\begin{array}{l}\text { Silver dimethyldithiocarbamate spectrophotometric } \\
\text { method }\end{array}$ & GB/T 17134-1997 & 0.5 \\
\hline $\mathrm{Cu}$ & Flame Atomic Absorption Spectrophotometry & GB/T 17138-1997 & 1.0 \\
\hline $\mathrm{Pb}$ & $\begin{array}{l}\text { KI-MIBK Extraction Flame Atomic Absorption } \\
\text { Spectrophotometry }\end{array}$ & GB/T 17140-1997 & 0.2 \\
\hline $\mathrm{Cr}$ & Flame Atomic Absorption Spectrophotometry & HJ 491-2009 & 5 \\
\hline $\mathrm{Zn}$ & Flame Atomic Absorption Spectrophotometry & GB/T 17138-1997 & 0.5 \\
\hline $\mathrm{Ni}$ & Flame Atomic Absorption Spectrophotometry & GB/T 17139-1997 & 5 \\
\hline
\end{tabular}

(2) Heavy metal elements Soil and sediment measurements Data Table 2.6 and Table 2.7: 
Table 2.6

Soil Element Measurement Data

\begin{tabular}{cccccccc}
\hline $\begin{array}{c}\text { Detection } \\
\text { Indicator }\end{array}$ & $\mathrm{S} 1$ & $\mathrm{~S} 2$ & $\mathrm{~S} 3$ & $\mathrm{~S} 4$ & $\mathrm{~S} 5$ & $\mathrm{~S} 6$ & $\mathrm{unit}$ \\
\hline $\mathrm{pH}$ & 6.87 & 7.21 & 7.38 & 7.46 & 7.04 & 7.33 & Dimensionless \\
$\mathrm{Cd}$ & 0.021 & 0.020 & 0.032 & 0.07 & 0.07 & 0.07 & $\mathrm{mg} / \mathrm{kg}$ \\
$\mathrm{Hg}$ & 0.012 & 0.015 & 0.017 & 0.008 & 0.011 & 0.012 & $\mathrm{mg} / \mathrm{kg}$ \\
$\mathrm{As}$ & 4.35 & 5.15 & 4.58 & 8.51 & 6.31 & 5.89 & $\mathrm{mg} / \mathrm{kg}$ \\
$\mathrm{Cu}$ & 16.1 & 12.3 & 15.0 & 15.1 & 10.3 & 10.2 & $\mathrm{mg} / \mathrm{kg}$ \\
$\mathrm{Pb}$ & 4.18 & 4.10 & 4.57 & 15.6 & 15.5 & 12.0 & $\mathrm{mg} / \mathrm{kg}$ \\
$\mathrm{Cr}$ & 32.8 & 32.9 & 31.9 & 44.3 & 42.5 & 37.2 & $\mathrm{mg} / \mathrm{kg}$ \\
$\mathrm{Zn}$ & 1.52 & 1.59 & 1.46 & 5.95 & 5.63 & 6.03 & $\mathrm{mg} / \mathrm{kg}$ \\
$\mathrm{Ni}$ & 12.7 & 14.8 & 12.3 & 36.1 & 30.7 & 18.3 & $\mathrm{mg} / \mathrm{kg}$ \\
\hline
\end{tabular}

Table 2.7

Sediment Element Measurement Data

\begin{tabular}{|c|c|c|c|c|c|}
\hline $\begin{array}{l}\text { Detection } \\
\text { Indicator }\end{array}$ & $1 \#$ & $2 \#$ & $3 \#$ & $4 \#$ & unit \\
\hline $\mathrm{pH}$ & 7.34 & 7.81 & 7.22 & 7.63 & Dimensionless \\
\hline $\mathrm{Cd}$ & 0.035 & 0.022 & 0.029 & 0.035 & $\mathrm{mg} / \mathrm{kg}$ \\
\hline $\mathrm{Hg}$ & 0.012 & 0.009 & 0.010 & 0.015 & $\mathrm{mg} / \mathrm{kg}$ \\
\hline As & 0.32 & 0.26 & 0.28 & 0.19 & $\mathrm{mg} / \mathrm{kg}$ \\
\hline $\mathrm{Cu}$ & 5.1 & 0.8 & 1.36 & 9.96 & $\mathrm{mg} / \mathrm{kg}$ \\
\hline $\mathrm{Pb}$ & 4.18 & 0.16 & 2.01 & 9.93 & $\mathrm{mg} / \mathrm{kg}$ \\
\hline $\mathrm{Cr}$ & 25.3 & 4.2 & 4.6 & 27.9 & $\mathrm{mg} / \mathrm{kg}$ \\
\hline $\mathrm{Zn}$ & 7.47 & 0.23 & 0.10 & 28.1 & $\mathrm{mg} / \mathrm{kg}$ \\
\hline $\mathrm{Ni}$ & 13.2 & 2.3 & 3.4 & 11.6 & $\mathrm{mg} / \mathrm{kg}$ \\
\hline
\end{tabular}

IV EVALUATION AND ANALYSIS OF RESULTS

Evaluation of soil environmental quality is generally based on the standard limits of «Soil Environmental Quality Standa» (GB15618-1955) [11], In this paper, we mainly use the single factor and Nemero index to evaluate the content of various metal elements in the soil.

A. Soil pH grade and soil metal element background values
For the $\mathrm{pH}$ in the soil, the soil scientist uses it to represent the hydrogen ion concentration in the soil sample [12]. We usually use the $\mathrm{pH}$ value to represent the relative $\mathrm{pH}$, through the determination of $\mathrm{pH}$, you can generally understand the evaluation of soil quality in the region, but also for the background of the various elements of the soil to provide a corresponding reference basis [13], The soil $\mathrm{pH}$ grades are as follows: Table 3.1:

Table 3.1

Classification of Soil $\mathrm{pH}$

\begin{tabular}{|c|c|c|c|c|c|c|c|c|c|}
\hline $\mathrm{pH}$ & $<4.5$ & $4.5 \sim 5.5$ & $\begin{array}{c}5.5 \sim \\
6.0\end{array}$ & $6.0 \sim 6.5$ & $\begin{array}{c}6.5 \sim \\
7.0\end{array}$ & $7.0 \sim 7.5$ & $7.5 \sim 8.5$ & $8.5 \sim 9.5$ & $>9.5$ \\
\hline rank & $\begin{array}{c}\text { Very } \\
\text { strong } \\
\text { acidity }\end{array}$ & $\begin{array}{l}\text { Strong } \\
\text { acidity }\end{array}$ & acidity & $\begin{array}{l}\text { Weak } \\
\text { acidity }\end{array}$ & neutral & $\begin{array}{l}\text { Weakly } \\
\text { alkaline }\end{array}$ & alkaline & $\begin{array}{c}\text { Strong } \\
\text { alkaline }\end{array}$ & $\begin{array}{c}\text { Very } \\
\text { strong } \\
\text { alkaline }\end{array}$ \\
\hline
\end{tabular}


Environment. Technology. Resources, Rezekne, Latvia Proceedings of the $11^{\text {th }}$ International Scientific and Practical Conference. Volume III, 192-199

Soil background value refers to the composition and content of chemical elements in the soil which are not affected by human activities [14]. Soil background value is not only the standard of environmental quality, but also the basis of various soil pollution evaluation methods [15]. The soil environmental quality standards (GB15618-1955) $\mathrm{mg}$ / $\mathrm{kg}$ as shown in Table 3.2: Table 3.2

Soil Environmental Quality Standard (GB15618-1955)

\begin{tabular}{|c|c|c|c|c|c|c|}
\hline & \multirow[b]{2}{*}{ Soil pH } & Level one & \multicolumn{3}{|c|}{ Level two } & \multirow{2}{*}{$\begin{array}{c}\text { Levelthree } \\
>7.5\end{array}$} \\
\hline & & $\begin{array}{c}\text { Natural } \\
\text { background }\end{array}$ & $<6.5$ & $6.5 \sim 7.5$ & $>7.5$ & \\
\hline & $\mathrm{Cd} \leq$ & 0.2 & 0.3 & 0.3 & 0.6 & 1.0 \\
\hline & $\mathrm{Hg}<$ & 0.15 & 0.3 & 0.5 & 1.0 & 1.5 \\
\hline \multirow{2}{*}{ As } & Paddy fields $\leq$ & 15 & 30 & 25 & 20 & 30 \\
\hline & dry land $\leq$ & 15 & 40 & 30 & 25 & 40 \\
\hline \multirow{2}{*}{$\mathrm{Cu}$} & Farmland $\mathrm{n}<$ & 35 & 50 & 30 & 100 & 400 \\
\hline & orchard $\leq$ & -- & 150 & 100 & 100 & 400 \\
\hline \multirow{5}{*}{$\mathrm{Cr}$} & $\mathrm{Pb} \leq$ & 35 & 250 & 300 & 350 & 500 \\
\hline & Paddy fields $\leq$ & 90 & 250 & 300 & 350 & 400 \\
\hline & dry land $\leq$ & 90 & 150 & 200 & 250 & 300 \\
\hline & $\mathrm{Zn} \leq$ & 100 & 200 & 250 & 300 & 500 \\
\hline & $\mathrm{Ni} \leq$ & 40 & 40 & 50 & 60 & 200 \\
\hline
\end{tabular}

B.Single Factor Index and Nemal Index

The so-called single factor evaluation is the evaluation of the degree of influence on an element or compound in the soil [16]. The evaluation is based on the individual accumulation index Pi of the material. The advantage of this method is that these transformations are linear, and the value of the attribute before and after the change is proportional [17], only need to calculate the individual indicators of soil elements and the calculation is relatively simple [18]. The single factor pollution index environmental quality evaluation criteria in Table 3.3 [19]:

Single factor index formula [20]:

$$
P_{i}=\frac{C_{i}}{S_{i}}
$$

Where Pi - soil i pollutant environmental index;

$\mathrm{Ci}$ - Measured concentration of soil i contaminants (mg / kg);

$\mathrm{Si}$ - soil i pollutants evaluation criteria (mg / $\mathrm{kg}$ ) (generally take II types of standards);

Table 3.3

Single Factor Pollution Index Environmental Quality Evaluation Standards in Table

\begin{tabular}{|c|c|c|c|}
\hline rank & $\mathrm{P}_{\mathrm{i}}$ value & Comparison of measured and background values & Pollution assessment \\
\hline I & $\mathrm{P}_{\mathrm{i}} \leq 1$ & similar & No pollution \\
\hline II & $1<\mathrm{P}_{\mathrm{i}} \leq 2$ & Higher than the background value below the pollution start value & Slight contamination \\
\hline III & $2<\mathrm{P}_{\mathrm{i}} \leq 3$ & Higher than the pollution start value & Mild contamination \\
\hline IV & $3<\mathrm{P}_{\mathrm{i}} \leq 5$ & More than 1 times the initial value of pollution & Moderately polluted \\
\hline $\mathrm{V}$ & $\mathrm{P}_{\mathrm{i}}>5$ & More than 2 times the initial value of pollution & Severe pollution \\
\hline
\end{tabular}

The comprehensive evaluation method for a region can be used to evaluate the multi - factor, including the Nemero comprehensive index method and the overlap index method with weights. In this paper, the evaluation of the heavy metal elements in the soil is mainly based on the Nemeru comprehensive index method. The advantage is not only to consider the average accumulation of various chemical elements of the material level, but also reflects the accumulation of the most serious chemical substances to the extent of the harm to the environment [21]. The evaluation criteria for the environmental quality of the Nemero pollen index are shown in Table 3.4 [22]:

Nemero comprehensive index method formula [23]:

$$
P_{\text {int egrated }}=\sqrt{\frac{\left(C_{i} / S_{i}\right)^{2} \max +\left(C_{i} / S_{i}\right)^{2} a v}{2}}
$$

Where Pintegrated - a comprehensive pollution index in a region;

$(\mathrm{Ci} / \mathrm{Si}) \max$ - the maximum pollution index in soil contaminants;

(Ci / Si) av - the average pollution index in soil contaminants; 
Table 3.4

Nemero Pollutants Environmental Quality Assessment Criteria

\begin{tabular}{ccccc}
\hline rank & Pintegrated value & Comparison of measured and background values & Pollution assessment \\
I & Pintegrated $\leq 0.85$ & A variety of metals are at the background level & Clean (safe) \\
II & $0.85<$ Pintegrated $\leq 1.75$ & One or more of the background values & Mild contamination \\
III & $1.75<$ Pintegrated $\leq 2.56$ & One or more of which has clearly exceeded the & Moderately polluted \\
IV & Pintegrated $>2.56$ & One or more has far exceeded the background & value & Severe pollution \\
\hline
\end{tabular}

C. Soil and Sediment Single Factor Index and Nemerot Pollution Index

According to the range of $\mathrm{pH}$, to determine the environmental quality standard selected soil background value of the evaluation level, and then through the single factor index and Nemero pollution index evaluation formula calculated data,the Nemero pollution index are shown in Table 3.5, single factor sediment soil data are shown in Table 3.6, Integrated Pollutant Soil Index are shown in Table 3.7 and Integrated Pollution Index Sediment Index are shown in Table 3.8 .

Table 3.5

Single Factor Soil Data

\begin{tabular}{ccccccc}
\hline $\begin{array}{r}\text { Detection } \\
\text { Indicator }\end{array}$ & $\mathrm{S} 1$ & $\mathrm{~S} 2$ & $\mathrm{~S} 3$ & $\mathrm{~S} 4$ & $\mathrm{~S} 5$ & $\mathrm{~S} 6$ \\
\hline $\mathrm{Cd}$ & 0.070 & 0.067 & 0.107 & 0.233 & 0.233 & 0.233 \\
$\mathrm{Hg}$ & 0.024 & 0.030 & 0.034 & 0.016 & 0.022 & 0.024 \\
$\mathrm{As}$ & 0.145 & 0.172 & 0.153 & 0.284 & 0.210 & 0.196 \\
$\mathrm{Cu}$ & 0.537 & 0.410 & 0.500 & 0.503 & 0.343 & 0.340 \\
$\mathrm{~Pb}$ & 0.014 & 0.014 & 0.015 & 0.052 & 0.052 & 0.040 \\
$\mathrm{Cr}$ & 0.164 & 0.165 & 0.160 & 0.222 & 0.213 & 0.186 \\
$\mathrm{Zn}$ & 0.006 & 0.006 & 0.006 & 0.024 & 0.023 & 0.024 \\
$\mathrm{Ni}$ & 0.254 & 0.296 & 0.246 & 0.722 & 0.614 & 0.366 \\
\hline
\end{tabular}

Table 3.6

Single Factor Sediment Data

\begin{tabular}{ccccc}
\hline Detection Indicator & $1 \#$ & $2 \#$ & $3 \#$ & $4 \#$ \\
\hline $\mathrm{Cd}$ & 0.117 & 0.073 & 0.097 & 0.117 \\
$\mathrm{Hg}$ & 0.024 & 0.018 & 0.020 & 0.030 \\
$\mathrm{As}$ & 0.013 & 0.010 & 0.011 & 0.008 \\
$\mathrm{Cu}$ & 0.170 & 0.027 & 0.045 & 0.332 \\
$\mathrm{~Pb}$ & 0.014 & 0.001 & 0.007 & 0.033 \\
$\mathrm{Cr}$ & 0.084 & 0.014 & 0.015 & 0.093 \\
$\mathrm{Zn}$ & 0.030 & 0.001 & 0.000 & 0.112 \\
$\mathrm{Ni}$ & 0.264 & 0.046 & 0.068 & 0.232 \\
\hline
\end{tabular}

Table 3.7

Integrated Pollutant Soil Index

\begin{tabular}{ccccccc}
\hline Point & S1 & S2 & S3 & S4 & S5 & S6 \\
\hline Pintegrated value & 0.395 & 0.308 & 0.370 & 0.542 & 0.459 & 0.286 \\
\hline
\end{tabular}


Environment. Technology. Resources, Rezekne, Latvia Proceedings of the $11^{\text {th }}$ International Scientific and Practical Conference. Volume III, 192-199

Table 3.8

Integrated Pollution Index Sediment Index

\begin{tabular}{cccccc}
\hline point & $\mathbf{1 \#}$ & $\mathbf{2 \#}$ & $\mathbf{3 \#}$ & $\mathbf{4 \#}$ \\
\hline Pintegrated value & 0.197 & 0.055 & 0.071 & 0.243
\end{tabular}

In order to visually and clearly compare the pollution of each point, The Pintegrated value of the each soil and sediment points are shown in a histogram shown in Figure 3.1 and 3.2:

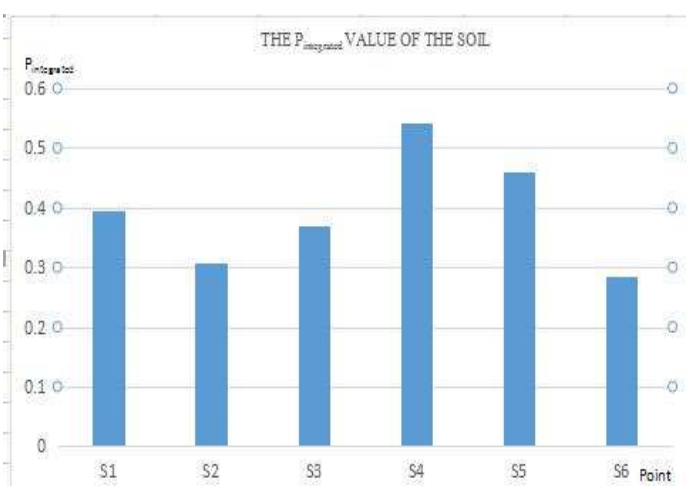

Figure 3.1 Soil Pintegrated Value

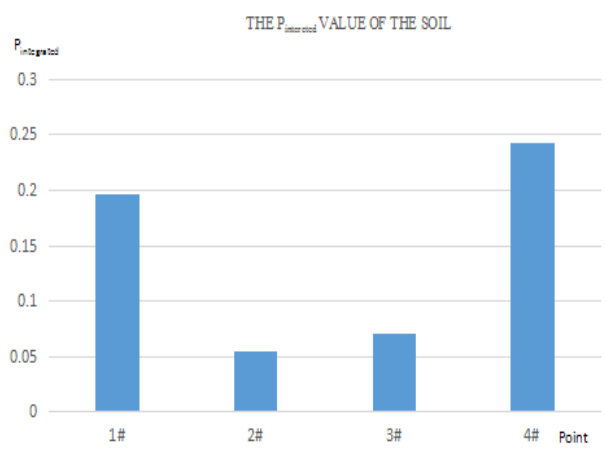

Figure 3.2 Sediment Pintegrated Value

\section{Results analysis and summary}

The results of the evaluation of soil and sediment according to single factor index and Nemerot pollution index method are as follows:

single factor index evaluation

The results of six points and four sediment points calculation of soil using single factor index formula show that show that the $\mathrm{Pi}$ value of $\mathrm{Cu}$ in soil $1 \sim 4$ is the highest and the pollution of $\mathrm{Cu}$ is the most serious. Point Pi and S6 Ni Pi value of the largest, Ni pollution is most serious. The Pi values of S1, S2, S3 and $\mathrm{S} 6 \mathrm{Zn}$ are the smallest and the pollution of $\mathrm{Zn}$ is the smallest. The Pi value of 1 \# and 4 \# $\mathrm{Ni}$ in the sediment is the highest, the Ni pollution is the most serious, the Pi value of 2 \# and 3 \# Cd is the largest, the $\mathrm{Cd}$ pollution is the most serious, the Pi value of 1 \# As is the smallest, the As pollution is the lightest, and $\mathrm{Pi}$ value of 3 \# $\mathrm{Zn}$ is the smallest, $\mathrm{Zn}$ pollution is the lightest, the Pi value of 4 \# Hg is the smallest, and the pollution of $\mathrm{Hg}$ is the lightest.

The results of single factor index show that the Pi values of soil and sediment are less than 1, belong to grade I, and there is no heavy metal pollution compared with soil environmental quality standard (GB15618-1955).

(2) The Calculation Results of Soil and Sediment at the Point of Nemero Pollutant Index

The results show that the Pintegrated value of S4 is the largest and the pollution is the most serious, and the Pintegrated value of S6 is the smallest and the pollution is the lightest. Sediment 4 \#Pintegrated maximum value of the most serious pollution, 3 \# Pintegrated minimum value of the smallest, the smallest pollution.

The calculation of the pollution index from Nemero indicated that the Pintegrated value of soil and sediment was less than 0.85 and belonged to grade I, and there was no pollution compared with soil environmental quality standard (GB15618-1955).

The results of the evaluation of soil and sediment by single factor index and Nemero pollen index show that the contents of $\mathrm{Cu}, \mathrm{Ni}$ and $\mathrm{Cd}$ in heavy metals around Liaohe facade stone mining are relatively high. $\mathrm{Zn}, \mathrm{Hg}$ content is relatively low, but according to the soil environmental quality standards (GB15618-1955) to evaluate, are within the level of I, and no heavy metal pollution. From the two evaluation criteria of the mining area of heavy metal control is better, the environment did not bring a greater threat.

\section{REFERENCES}

[1] Chen Chen. a typical area of heavy metal pollution status and evaluation in Anhui Province[D]. Hefei University of Technology, 2013. (in Chinese)

[2] Shao Li, Xiao Huayun, Wu pity, Tang Congguo.Advances in Heavy Metal Pollution of Traffic Sources [J]. Earth and Environment, 2012, (03): 445-459. (in Chinese)

[3] Zhang Qing. Soil heavy metal spectroscopy detection method [J]. Jiangxi Building Materials, 2016, (08): 291-292. (in Chinese)

[4] Wang Mei, Li Shutian. Fertilizer Heavy Metal Content and Effects of Fertilization on Heavy Metal Accumulation in Soil and Crops [J]. Journal of Plant Nutrition and Fertilizer Science, 2014, (02): 466-480. (in Chinese)

[5] Feng Yanhong, Wang Guoqing, Ying Rongrong, Zhao Xin, Zheng Liping, Zhou Yan, Zhu Xin, Lin Yu lock. Study on Pretreatment Method for Determination of Total Mercury in Soil [J]. Environmental Science and Technology, 2014, (09): 87-91. (in Chinese)

[6] Qi Wenqi, Cao Jishan, Lu Minghuai.Comparison of Dissolution of $\mathrm{Pb}, \mathrm{Cr}, \mathrm{Ni}, \mathrm{Cd}, \mathrm{Mn}, \mathrm{Cu}$ and $\mathrm{Zn}$ in Typical Soil Samples by Several Dissolution Methods [J]. Drought Environmental Monitoring, 1990, (04): 179-183. (in Chinese)

[7] XIAO Ming, YANG Wen-jun, SUN Xiao-feng, LV Xin.Effects of Soil As Dynamic on the Quality Evaluation and Environmental Risk Prediction [J].Agricultural Resources and Environment, 2014, (03): 273-278. (in Chinese)

[8] Xie Tao, Luo Yan. Determination of Total Mercury in Soils by Direct Mercury [J]. Spectroscopy Laboratory. 2012 (03) (in Chinese) 
[9] Wang Lina, Si Hongyan, Fu Huafeng. Determination of $\mathrm{Cu}$, $\mathrm{Zn}, \mathrm{Pb}, \mathrm{Cd}, \mathrm{Cr}$ and $\mathrm{Ni}$ in Sewage Sludge by Flame Atomic Absorption Spectrometry [J]. Journal of Xuchang University, 2010, (02 ): 91-95. (in Chinese)

[10] Qi Wenqi, Cao Jishan, Dai Wenhong.Comparison of Pb, Cr, $\mathrm{Ni}, \mathrm{Cd}, \mathrm{Mn}, \mathrm{Cu}$ and $\mathrm{Zn}$ in Three Kinds of Soil by Different Acidic Methods [J]. China Environmental Monitoring, 1991, (03): 47-50. (in Chinese)

[11] Zhang Xiaolei, Kong Linghui, He Kuan, Fu Yan. Henan University campus soil heavy metal status and its evaluation [J]. Journal of Luoyang Normal University, 2006, (05): 145148. (in Chinese)

[12] Feng Guoming. Determination of soil pH [J]. Friends of the rich farmers, 2000, (10): 14. (in Chinese)

[13] Wu Lingzhen.Study on urban soil environmental quality evaluation based on soil heavy metal [D]. Southwest University, 2013. (in Chinese)

[14] MA Hui-ying.Research on soil background value of Ebinur Lake Basin [D]. Xinjiang University, 2010.

[15] Wei Fusheng, Chen Jingsheng, Wu Yanyu, Zheng Chunjiang. Study on Soil Environmental Background Value in China [J]. Environmental Science, 1991, (04): 12-19. (in Chinese)

[16] YANG Xu, ZENG Xiang-liang.Evaluation of water quality of Meiyu Lake in Zhengzhou University based on single factor evaluation method and pollution index method $[\mathrm{J}]$. Jiangsu Science and Technology Information, 2014, (05): 51-53. (in Chinese)
[17] Luo Fang, Wu Guorong, Wang Chong, Zhang Lin. Nemero pollution index method and single factor evaluation method in water quality evaluation [J]. Environment and Sustainable Development, 2016, (05): 87-89. (in Chinese)

[18] Spatial distribution and contamination assessment of heavy metals in surface soils of Hassi Messaoud, Algeria[J] . Mohammed L. Benhaddya,Mohammed Hadjel. Environmental Earth Sciences . 2014 (3)

[19] Li Xiaolong. Evaluation of soil heavy metal pollution in a smelter in Tongguan County, Shaanxi Province [D]. Northwest A \& F University, 2014. (in Chinese)

[20] Li Renzhe. A rare metal plant environmental pollution assessment of the status quo and its impact on the quality of the plant [D]. Northwestern Polytechnical University, 2006. (in Chinese)

[21] Liang Bao. Yong Bridge area high risk area river coastal soil heavy metal pollution and ecological risk assessment [D] Anhui Medical University, 2016. (in Chinese)

[22] KONG Fan-bin, LIU Yang.Comparison of single factor index method and Nemero index method in soil environmental quality evaluation [J]. Gansu Science and Technology, 2014, (03): 21-22. (in Chinese)

[23] Zhang Yulian, Yan Tianzeng. Application of Nemero Index Method in Soil Heavy Metal Pollution Evaluation [J]. Journal of Henan Institute of Education (Natural Science Edition), 2012, (02): 35-39. (in Chinese) 